
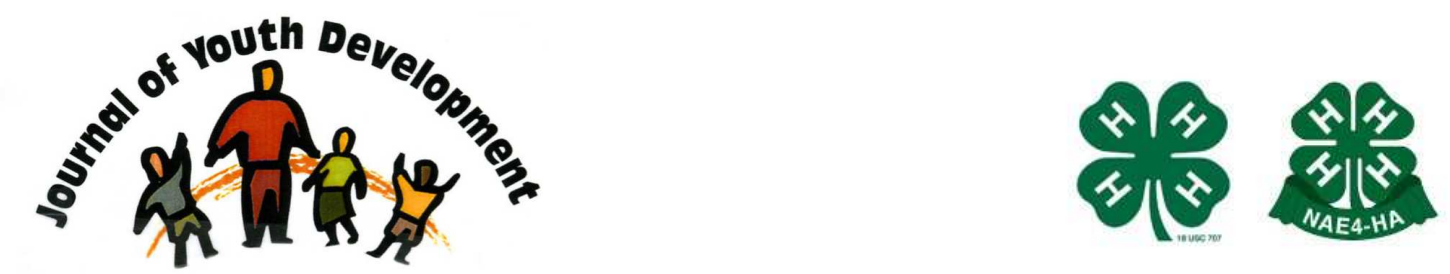

Bridging Research \& Practice

\title{
Bers's Theory of Positive Technological Development
}

\author{
Steven Worker \\ Agriculture and Natural Resources \\ University of California \\ Davis, CA \\ smworker@ucanr.edu
}




\title{
JOURNAL OF YOUTH DEVELOPMENT \\ bridging research and practice

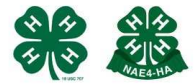

Volume 9, Number 1, Special Edition 2014

Article 140901RR001

\section{Bers's Theory of Positive Technological Development}

\author{
Steven Worker \\ University of California
}

\begin{abstract}
This resource review provides an introduction to Mariana Bers' new book, Designing Digital Experiences for Positive Youth Development (2012). Bers applies the Six C model of Positive Youth Development (PYD) to the digital domain with her theoretical model, Positive Technological Development. The model may be particularly valuable for practitioners seeking to design digital experiences for youth, as well as for evaluators who assess the PYD outcomes associated with youth participation in these spaces.
\end{abstract}

\section{Introduction}

This article is a review and overview of Bers, M. (2012). Designing Digital Experiences for Positive Youth Development. New York: Oxford University Press, Inc.

Youth in the United States spend substantial amounts of time participating in activities that involve digital technologies. In her recent book, Mariana Bers advocates for the design of digital opportunities that promote positive youth development. Using the metaphor of landscape design, she argues that designers of digital programs should strive to provide:

- young children with a digital playground, not a virtual playpen. The "playground promotes, while the playpen hinders, a sense of mastery, creativity, self-confidence, and open exploration" (p. 23).

- elementary youth a multimedia park, not a virtual mall. Parks are places of creation while malls are venues of consumption.

- high school adolescents with a palace in time, not simple wireless hangouts. Online environments should support purposeful explorations of identity, self-reflection, creativity, and community participation.

For designers of digital environments, the question becomes: how do we best promote playgrounds, parks, and a palace in time, referred to more broadly as positive youth development, in these online spaces? 
Bers embraces the Six C Model of Positive Youth Development (PYD) (Lerner, 2004) and extends the C's to the domain of digital technologies with her theoretical model, Positive Technological Development (PTD). The PTD framework incorporates three aspects: individual assets defined by the 6 C's of PYD, technology-mediated activities that link with the individual assets, and situated practice in various contexts. The value of PTD is in its linkage to the 6 C's model of PYD, a model developed through empirical research (e.g., Lerner, et al., 2012). The PTD framework provides guidance on the types of digital and media activities, experiences, and programs that promote positive technological development by linking the 6 C's to specific technology-mediated behaviors. Abrief overview and synthesis of PTD is provided below in Table 1.

Table 1

Connections between the 6 C's of Positive Youth Development (PYD) and Positive Technological Development (PTD)

\begin{tabular}{|c|c|c|c|}
\hline $\begin{array}{l}6 \text { C's of PYD } \\
\text { Individual } \\
\text { Assets } \\
\text { (Lerner, 2004) }\end{array}$ & $\begin{array}{l}\text { PTD } \\
\text { Technology- } \\
\text { Mediated } \\
\text { Behavior }\end{array}$ & Description of the PTD Construct & $\begin{array}{l}\text { Theoretical } \\
\text { Underpinning of } \\
\text { the PTD Construct }\end{array}$ \\
\hline Competence & Content Creation & $\begin{array}{l}\text { Creation of personally meaningful } \\
\text { projects; youth become producers, not } \\
\text { consumers; youth develop competency in } \\
\text { participatory online culture. }\end{array}$ & $\begin{array}{l}\text { Constructionism } \\
\text { (Papert, 1980) and } \\
\text { new digital literacies } \\
\text { (e.g., Jenkins, 2009) }\end{array}$ \\
\hline Confidence & Creativity & $\begin{array}{l}\text { Development of self-efficacy through } \\
\text { experiences supportive of creative } \\
\text { expression, sharing, and reflecting. }\end{array}$ & $\begin{array}{l}\text { Creativity (Resnick, } \\
\text { 2007; Sawyer, 2006) } \\
\text { and Flow } \\
\text { (Csikszentmihalyi, } \\
\text { 2000) }\end{array}$ \\
\hline Character & $\begin{array}{l}\text { Choices of } \\
\text { Conduct }\end{array}$ & $\begin{array}{l}\text { A bounded playground with freedom for } \\
\text { youth to make choices, take risks, } \\
\text { experience consequences, and reflect; } \\
\text { experiment with moral and ethical issues } \\
\text { and community norms. }\end{array}$ & $\begin{array}{l}\text { Moral development } \\
\text { (e.g., Kohlberg, } \\
\text { 1976) }\end{array}$ \\
\hline Connection & Communication & $\begin{array}{l}\text { Synchronous and asynchronous } \\
\text { communication through multimedia (text, } \\
\text { voice, sound, video, etc.); development of } \\
\text { language and literacy; promotion of } \\
\text { connections between youth and adults. }\end{array}$ & $\begin{array}{l}\text { Communication and } \\
\text { computer-mediated } \\
\text { communication (e.g., } \\
\text { Herring, 2002) }\end{array}$ \\
\hline Caring & Collaboration & $\begin{array}{l}\text { Common tasks require that youth depend } \\
\text { and respond to each other; experience } \\
\text { includes technical and social supports } \\
\text { from peers and adults; youth use } \\
\text { technology to help others. }\end{array}$ & $\begin{array}{l}\text { Computer-supported } \\
\text { collaborative learning } \\
\text { (e.g., Stahl, } \\
\text { Koschmann, \& } \\
\text { Suthers, 2006); } \\
\text { Communities of } \\
\text { Practice (Lave } \\
\text { \&Wenger, 1991) }\end{array}$ \\
\hline Contribution & $\begin{array}{l}\text { Community- } \\
\text { Building }\end{array}$ & $\begin{array}{l}\text { Shared sense of community responsibility; } \\
\text { mechanisms for contributions to the } \\
\text { common good; experiencing democratic } \\
\text { participation. }\end{array}$ & $\begin{array}{l}\text { Youth civic } \\
\text { engagement (e.g., } \\
\text { Middaugh, 2012) }\end{array}$ \\
\hline
\end{tabular}


The application of Bers's framework provides program developers and researchers with criteria in designing and/or evaluating digital experiences. The PTD framework moves forward the digital/media literacy discussion, often framed as youth-as-consumers of media instead of youth as contributors in a participatory culture. In other words, PTD responds to the question of how we use technology to help youth become not only technological fluent, but become thriving people that contribute to their communities.

The C's (in both PYD and PTD) interact and impact each other, but are artificially separated for ease of understanding. Since the PTD framework extends the $6 \mathrm{C}$ model of PYD, it experiences similar limitations, namely that the $6 \mathrm{C}$ model is one among many theoretical models attempting to explain the process and programs of youth development (Lerner, et al., 2011). The 6 C's do not represent a broad consensus across practitioners, let alone researchers, in being the factors universally contributing to youth thriving (King, et al., 2005). While Bers broadly applies her framework to a wide variety of technologies, from educational robotics to online communities, PTD is by no means an exhaustive list of everything designers will encounter or should consider in developing digital experiences for youth.

Readers interested in the Positive Technological Development framework, including empirical research, may find additional information from Bers and colleagues (2008, 2010, 2012).

\section{References}

Bers, M.U. (2008). Blocks to robots: Learning with technology in the early childhood classroom. New York: Teachers College Press.

Bers, M.U. (2010). Beyond computer literacy: Supporting youth's positive development through technology. New Directions for Youth Development, 128, 13-23.

Bers, M.U., Doyle-Lynch, A., \& Chau, C. (2012). Positive technological development: The multifaceted nature of youth technology use toward improving self and society. In C. Carter Ching \&. Foley, B.J. (Eds.). Constructing the Self in a Digital World (Learning in Doing: Social, Cognitive and Computational Perspectives). Cambridge University Press.

Csikszentmihalyi, M. (2000). Flow: The psychology of optimal experience. New York: HarperCollins.

Herring, S. (2002). Computer-mediated communication on the Internet. Annual Review of Information science and Technology, 36(1), 109-168.

Jenkins, H. (2009). Confronting the challenges of paticipatory culture: Media education for the 21st century. Cambridge, MA: The MIT Press.

King, P.E., Dowling, E.M., Mueller, R.A., White, K., Schultz, W., Osborn, P., et al. (2005). Thriving in adolescence: The voices of youth-serving practitioners, parents, and early and late adolescents. The Journal of Early Adolescence, 25(1), 94-112. 
Kohlberg, L. (1976). More stages and moralization: The cognitive-developmental approach. In T. Lickona (Ed.), Moral development and behavior: Theory, research and social issues. New York: Holt, Rinehart \& Winston.

Lave, J., \& Wenger, E. (1991). Situated learning: Legitimate peripheral participation. Cambridge University Press.

Lerner, R. (2004). Liberty: Thriving and civic engagement among America's youth. Thousand Oaks, CA: Sage Publications, Inc.

Lerner, R.M., Lerner, J.V., Lewin-Bizan, S., Bowers, E.P., Boyd, M.J., Mueller, M.K., et al. (2011c). Positive youth development: Process, programs, and problematics. Journal of Youth Development, 6(3), 41-64

Lerner, R.M., Lerner, J.V., et al. (2012). The positive development of youth: Report of the findings from the first eight years of the 4-H study of positive youth development. Tufts University Institute for Applied Research in Youth Development and the National 4-H Council.

Middaugh, E. (2012). Service and activism in the digital age: Supporting youth engagement in public life (DML Central Working Papers). Retrieved from http://dmlcentral.net/resources/5010.

Papert, S. (1980/1993). Mindstorms: Children, computers, and powerful ideas (Second Ed.). New York: The Perseus Books Group.

Resnick, M. (2007). Sowing the seeds for a more creative society. Learning \& Leading with Technology, 35(4), 18-22.

Sawyer, R. (2006). Explaining creativity: The science of human innovation. New York: Oxford University Press.

Stahl, G., Koschmann, T., \& Suthers, D. (2006). Computer-supported collaborative learning: An historical perspective. In R. K. Sawyer (Ed.), The Cambridge Handbook of the Learning Sciences (pp. 409-425). Cambridge, UK: Cambridge University Press.

(c) Copyright of Journal of Youth Development $~$ Bridging Research and Practice. Content may not be copied or emailed to multiple sites or posted to a listserv without copyright holder's express written permission. Contact Editor at: patricia.dawson@oregonstate.edu for details. However, users may print, download or email articles for individual use.

ISSN 2325-4009 (Print); ISSN 2325-4017 (Online) 